\title{
Punishment for perpetrators of sexual harassment against women, as victims in the rich world in Indonesia
}

\author{
Helena LG \\ \{helenahestaria10@gmail.com\} \\ Universitas Pendidikan Ganesha, Indonesia ${ }^{1}$
}

\begin{abstract}
The development of information and communication technology (ICT) is currently very helpful for human activities, especially during the Covid-19 pandemic. With the existence of sophisticated technology during the COVID-19 pandemic, it can facilitate the flow of communication and information without being hindered by space, boundaries, distance and time, and can increase productivity and efficiency. However, it cannot be denied that with the development of information communication technology (ICT), new crimes in cyberspace, especially sexual harassment of women, are the biggest victims of being harassed in cyberspace. This harassment is carried out through social media such as Facebook, Instagram, Snapchat, and other social media. Perpetrators of crimes of sexual harassment in cyberspace in Indonesia can be sentenced to a criminal sanction which is contained in the Criminal Code and the ITE Law. The theory that the author uses in compiling this paper is library research and the purpose of this study is to monitor the position of women as the biggest victims of sexual harassment in cyberspace and how active sexual harassment perpetrators are in social media in the ITE Law.
\end{abstract}

Keywords: Learn from home; Covid-19; Higher education; Student perspectives; Motivation

\section{Introduction}

The globalization process of information and communication technology (ICT) in a rapidly developing world makes it easy for users to access the information they need with just one touch of a finger. The development of mobile phones, for example, in the past cell phones could only be used to talk and send short messages (SMS), but now cellphones have developed like a sophisticated mini computer. The sophistication of cellphones has developed very rapidly, previously using digital technology, now it has used touch screen technology and even this sophistication is increasing after being combined with certain features such as Android technology. The advancement of information technology (ICT) is closely related to the needs of the internet [1].

Along with the development of people's needs in the world, information technology (information technology) plays an important role, both in the present and in the future. Information technology is believed to bring great benefits and interests to countries in the world. There are at least two things that make information technology so important in spurring 
world economic growth. First, information technology encourages demand for technology products themselves, such as computers, modems, USB (Universal Serial Bus), and a means to build internet networks. Second, it can facilitate business transactions, especially financial businesses, in addition to other businesses[2].

Cybercrime is a crime that uses computer technology and the internet as its media, recently showing significant numbers, both in terms of quantity and quality. The use of computers and the internet as media to commit crimes is generally known as "cryber crime" (Agus Rahardjo, 2002: 92). Cyber-crime can also be defined as an act that violates the law by utilizing computer technology which is based on the sophistication of internet technology (Budi Raharjo, 2002: 23). As stated by Andi Hamzah in his book "Criminal Aspects in the Computer Field" (1989) which defines cyber-crime as a crime in the computer sector in general it can be interpreted as illegal use of computers. Meanwhile, according to Eoghan Casey (2001: 16) "Cybercrime is used throughout this text to refer to any crime that involves computer and networks, including crimes that do not rely heavily on computer[3].

However, currently the rate of crime through the internet network or (cybercrime) is not followed by the government's ability to keep up with it, making it difficult to control it. The emergence of several cybercrime cases in Indonesia has posed a high escalation threat to the stability of the social and security services. The government with its legal instruments has not been able to keep up with the techniques of crimes committed with computer technology, especially the internet network (internetwork). A criminal act is an act that is prohibited by law, which is accompanied by a criminal threat for anyone who violates the prohibition. In the formulation of a criminal act, there is always a legal object (abbreviated as object). The element regarding the object of a criminal act is an absolute element, it is always present in every formulation of a criminal act by law. This formulation does not mean that there is no element of the object of the crime. In criminal law, there are no exceptions. Often times we find exceptions in certain cases and circumstances from a certain norm or necessity in a norm. Exemplified in the formulation of persecution (Article $351 \mathrm{KUHP}$ ) which does not include the element of the object[4].

This is an exception from the necessity that the object of a mandatory legal act of a crime is an exception, it is the "necessity" to state the object in every formulation of a criminal act there are no exceptions[5]. There can be no exceptions. Nowadays, along with the development of the era, the problem of pornography and porno-action is getting more and more alarming, and the negative impact can be seen clearly, including frequent sexual harassment, adultery, rape and even murder. The people who are victims of this crime are not only adult women but many victims are still children, especially women.

\section{Method}

This research is a library research, therefore it is a technique used in data collection is literary data collection namely materials that are coherent with the objects of discussion in question[6]. The data in the literature is collected andprocessed by Editing, namely rechecking the data obtained, especially in terms of completeness, clarity of meaning and harmony of meaning between one with others, Organizing, namely organizing the data obtained with a framework that's already needed, Findings of research results, namely to carry out further analysis of the results of organizing data using rules, theories and predetermined method in order to obtain certain conclusions is the result of the answer to the problem 
formulation. The research design used a basic qualitative. According to this basic qualitative design, it is intended to produce a deep understanding of learning from home from data collected from students and then analyzed in the form of descriptive narratives. This qualitative design is an approach that is generally used to understand and interpret social phenomena in their natural [5]

\section{Result and Discussion}

During 2008-2020 Komnas Perempuan issued a red note related to the high escalation of victims of sexual violence in Indonesia. Based on his records, the increase in the number of victims of sexual violence in adult women increased by more than $700 \%$, girls victims increased by $65 \%$, victims of online sexual harassment increased by $300 \%$, and groups with disabilities increased by $47 \%$ in 1 (one) year from 2019- 2020. Then, based on data from the Women and Children Advocacy Institute, it was found that during the COVID-19 pandemic, the spike in online-based sexual violence cases also increased, which within half a year there were 4 (four) cases. This number is high because if we compare it to the 2019 report, the number of cases is 2 in a year. This phenomenon also includes data from victims who are willing to report and from other people who report immoral acts, not including hidden victims who do not report themselves to be victims of sexual violence. Simply put, the problem of sexual violence is still an iceberg phenomenon in Indonesia[6].

Based on cases of online gender based violence, KBGO is found on various social media platforms. The most common incidents occurred on Facebook, where $39 \%$ of women were sexually harassed. This figure is then followed by Instagram (23\%), Whatsapp (14\%), Snapchat (10\%), Twitter (9\%) and TikTok (6\%). Research shows that one in five girls have stopped or reduced their use of social media after such attacks, while one in ten changed the way they express themselves online as a form of self-protection[8]. According to the National Sexual Violence Research Center (NSVRC) Sexual violence occurs when a person is forced or manipulated by another person to engage in sexual activity that he does not want or without the party's consent. Anyone can become a victim of sexual violence, whether children, adolescents, adults and even the elderly. Perpetrators of sexual violence can be foreigners, people who are trusted by the victim and even family members. Sexual violence can take many forms, from rape, incest or incest, sexual violence with minors, sexual harassment, sexual exploitation, exposing genital parts or nudity to others, masturbating in public to seeing or peeking at someone's private activities. without the knowledge / permission of the party.

By reviewing targets or potential victims of sexual violence, in fact they can come from various age groups and genders. The Plan International survey found that in Indonesia alone, $38 \%$ of respondents experienced KBGO. This figure is well below the global average of $58 \%$. However, the number of KBGO cases itself is increasing. Komnas Perempuan's Annual Record (CATAHU) which reports on cases of harassment against women in 2019 shows an increase in complaints of cyber crime cases by $300 \%$ (from 97 cases in 2018 to 281 ). Of the various forms of KBGO that were reported to Komnas Perempuan, the most cases online took the form of threats and intimidation of the distribution of pornographic photos and videos of victims. Reporting of criminal acts of sexual harassment against women in technology and information media is currently constrained by various factors, one of which is that the victim will receive a louder scorn than the perpetrator then questions about how to dress and behavior, these two things justify the reason for the woman to receive sexual harassment, with 
women who Speaking up for what they experienced was considered only seeking attention and was considered telling lies and every time there was an incident of sexual harassment, not a few women and men felt that the victim did not need to share their story. Therefore, the role and interests of victims are the considerations of law enforcers in law enforcement practice, in particular the application stage of criminal law provisions, the types and sizes of the severity of the crimes imposed on the perpetrator are strongly influenced by the way and motivation of the perpetrator in realizing his crime, a criminal crime can be revealed by reports or complaints made by victims or the public. The position of women as victims of harassment in cyberspace, namely as victims who are basically the ones who suffer the most in a crime, do not receive as much protection as provided by law to criminals. Perpetrators of crimes are sentenced to criminal sanctions by the court, however the condition of the victims seems to be completely ignored, even though the issue of justice and respect for human rights does not only apply to the perpetrators of the crime but also the victims. Almost all of the principles of criminal procedure law adhered to by the Criminal Procedure Code prioritize the rights of suspects, there are at least ten principles adhered to by the Criminal Procedure Code with the intention of protecting the rights of citizens in a fair legal process[11]. In Law no. 11 of 2008 concerning Information and Electronic Transactions also does not have the term pornography, but "content that violates decency".

Electronic Information is a set of electronic data, including writing, voice, images, maps, drafts, photographs, electronic data interchange (EDI), electronic mail (electronic mail), telegram, telex, telecopy, or the like, letters, signs, numbers, Processed access codes, symbols, or perforations that have meaning or can be understood by those who are able to understand them[7]. The formulation of the criminal act of pornography on the Internet is regulated in Article 27 Paragraph 1 of the ITE Law which reads "every person intentionally and without right distributes and / or transmits and / or makes electronic information and / or electronic documents accessible which contain content that violates decency[8]. In the contents of Electronic Information and / or Documents, this article regulates the prohibition of the distribution of Electronic Information and / or Electronic Documents that have contents that violate decency. In Law Number 11 of 2008 concerning ITE, Article 45 Paragraph 1 also regulates the punishment carried out by perpetrators of sexual harassment or acts related to decency in Article 27 Paragraph 1 of the ITE Law which reads "everyone who fulfills the elements referred to in Article 27 Paragraph (1), (2), (3), and paragraph (4), shall be subject to imprisonment for a maximum of 6 (six years and / or a maximum fine of Rp.1,000,000,000.00 (one billion rupiah). It should be emphasized that this content contains a meaning bias, the meaning bias is the coercion of decency, whether civility or politeness is the meaning of the term morality in general or is the meaning referred to in morality is pornography which is identified with obscenity or eroticism[9].

In general understanding of law, there is a tendency to include pornography as part of the environment of decency and moral norms. Violations against him, including offenses against politeness. As in the Criminal Code itself does not formulate the definition of pornography, but based on the interpretation of Articles 281, 282, 283, 532, 534, and 535, the definition of pornography from these articles, as well as in articles 411 to 416, Article 420, and Article 422 The RUUKUHP term pornography is not explicitly stated and formulated, therefore the definition of pornography and porno-action according to the Draft Criminal Code can also be inferred from the articles that regulate the crime of decency. According to the large Indonesian dictionary, morality comes from the word susila which means that the language is not good, while pornography, which is to arouse lust or can also be interpreted as reading material that is deliberately and solely designed to arouse lust in sexs[10] 
The immorality of these acts is sometimes very dependent on public opinion at that time and place. That people having intercourse in the middle of the street destroy public decency (decency) is no longer a problem, but kissing in a public place in a big city is currently being done by the Indonesian people. Until now, the people of Jakarta are still not offended by the presence of women and men bathing at the river which can be seen from the public road naked or half naked, whether in the future[11]. If the understanding of the legislators is the same as morality in the true meaning of the term, it will be an implementation bias of this article. This is because the attitude of law enforcement itself will be fragmented according to the existence of the territory and the people faced by law enforcers. For example, in dealing with ethnic people who are different from one another, as well as their different religions, if this happens then the effectiveness of this article will experience many obstacles, it is different if what is included in this article is material content. pornography, according to the author, is more appropriate, because it is miniature, because according to its understanding, its enforcement will be more generally applicable to the Indonesian people. In addition, if it is synchronized with the Pornography Law, this will be harmonious, so that their enforcement will support each other in terms of preventing and overcoming pornography in Indonesia through positive law.

\section{Conclusion}

The position of women as victims of harassment in cyberspace, namely as victims who are truly the ones who suffer the most in a true crime do not receive as much protection as provided by law to criminals. Perpetrators of crimes are subject to criminal sanctions by the court, however the condition of the victims seems to be completely indifferent even though the issue of justice and respect for human rights applies not only to crimes but also to victims. Almost all of the principles of criminal procedure law adhered to by the Criminal Procedure Code prioritize the rights of suspects, there are at least ten principles adhered to by the Criminal Procedure Code with the intention of protecting the rights of citizens in a fair legal process[18]. Penalties for perpetrators of criminal acts of sexual harassment through social media are based on the Law on Information and Electronic Transactions 2008 in article 27 Paragraph 1, which states that acts that contain an element of decency and are posted on social media are subject to 6 years in prison or a fine of 1,000. 000,000 (one billion).

\section{References}

[1] S. Budiwibowo, "Membangun Pendidikan Karakter Generasi Muda Melalui Budaya Kearifan Lokal Di Era Global," Prem. Educ. J. Pendidik. Dasar dan Pembelajaran, vol. 3, no. 01, pp. 39-49, 2016.

[2] P. Nugraha, Satria Wibawa. Suatra, "Granting Criminal Sanctions as Ultimum Remedium in the Law of Environmental Protection and Management (In Bahasa)," Kerthawicara.

[3] K. Holtfreter, "Is occupational fraud 'typical' white-collar crime? A comparison of individual and organizational characteristics," J. Crim. Justice, vol. 33, no. 4, pp. 353-365, 2005.

[4] M. Suryani and A. Mashdurohatun, "Penegakan Hukum Terhadap Eksistensi Becak Bermotor Umum (Bentor) Berdasarkan Undang-Undang Nomor 22 Tahun 2009 Tentang Lalu Lintas Dan Angkutan Jalan," Pembaharuan Huk., vol. 3, no. 1, pp. 21-38, 2016.

[5] H.B. Sutopo, Metode Penelitian Kualitatif. Surakarta: Sebelas Maret University Press, 2006.

[6] BPKP, “Total Dana Penanganan Corona Rp. 800 T di 2020,” CNN Indonesia, 2020. 
[7] F. Wisnaeni, "PANDEMIC IMPACT OF COVID-19: MODERNIZATION AND DIGITALIZATION OF THE GENERAL ELECTION COMMISSION OF THE REPUBLIC OF INDONESIA (KPU-RI)," J. Ilm. Galuh Justisi, vol. 8, no. 2, 2020.

[8] S. Paramita and W. P. Sari, "Intercultural Communication to Preserve Harmony Between Religious Group in Jaton Village Minahasa (Komunikasi Lintas Budaya dalam Menjaga Kerukunan antara Umat Beragama di Kampung Jaton Minahasa),” J. Pekommas, 2016.

[9] M. P. Zenno, "PENERAPAN PRINSIP ULTIMUM REMEDIUM DALAM TINDAK PIDANA KORUPSI," J. Yudisial, 2017.

[10] N. Fajriana, "Teleconference Dalam Pemeriksaan Perkara Pidana Di Pengadilan," Badamai Law J., vol. 3, no. 1, p. $60,2018$.

[11] T. Pavone, "Political Culture and Democratic Homeostasis: A Critical Review of Gabriel Almond and Sidney Verba's The Civic Culture Tommaso Pavone ( tpavone@princeton.edu ), April 7 th , 2014 Synopsis Background on Structural Functionalism Almond and Verba ( 1963 )," vol. 37, no. 3, pp. 1-5, 2014. 